\title{
SYMPOSIUM ON PROSPER WEIL, “TOWARDS RELATIVE NORMATIVITY IN INTERNATIONAL LAW?”
}

\author{
PROSPER WEIL AND THE MASK OF CLASSICISM
}

\author{
John Tasioulas ${ }^{*}$
}

Prosper Weil's scintillating intervention of 1983 warned against pathological doctrinal tendencies that threatened to "disable international law from fulfilling what have always been its proper functions." "Weil concluded his sweeping critique of these supposed pathologies with an urgent call for remedial action: "[A]ll is not yet lost.... There is still time for jurists to react." "2 But, as José Alvarez points out in his contribution to this symposium, the manifestations of "relative normativity" that Weil decried-such as the doctrine of jus cogens and the transmutation of customary law into universal law-have only entrenched themselves more firmly in the decades since his famous article was published. ${ }^{3}$ So, what is the point of engaging with "Towards Relative Normativity in International Law?" today beyond its historical significance as a celebrated, but ultimately failed, rallying cry against the doctrinal revolution that has swept over international law in the period since decolonization?

I would answer this question in two ways. The first is that Weil's article gives eloquent expression to a theoretical approach to international law, which may be called the positivist/voluntarist approach (PVA), whose power and seductiveness deserves the tribute of serious critical examination. Weil's critique of specific doctrines that make up the relativist doctrinal trend is underpinned by a theoretical account of the "essential features" that international law requires in order to discharge its dual function of ensuring coexistence and cooperation among the states that constitute a radically pluralistic international society. ${ }^{4}$ The three "essential features" that Weil contends international law has acquired over the centuries to realize these functions are: voluntarism, which traces the bindingness of international norms to the individual consent of the states that are subject to them; religious and ideological neutrality; and positivism, which stresses the distinction between lex lata and lex ferenda and, more generally, erects a barrier against the use of value judgments in the identification of international law.

Of course, Weil's underlying theory is contestable at numerous points. But the key point I wish to emphasize is that Weil does not present the PVA as a brute commitment. On the contrary, he defends it within a broader teleological framework that articulates important values that define international law's distinctive functions. The focus on Weil's doctrinal criticisms, and his insistence on voluntarism, positivism, and neutrality, may have obscured the teleological framework within which his argument is elaborated. Moreover, even if one rejects Weil's or any other version of the PVA, there are serious questions about how international law can best secure

* Yeoh Professor of Politics, Philosophy, and Law, The Dickson Poon School of Law, King's College London. I am grateful to Adil Haque, Philippa Webb, and Ingrid Wuerth for very helpful comments on a previous version of this piece.

${ }^{1}$ Prosper Weil, Towards Relative Normativity in International Law?, 77 AJIL 413, 441 (1983).

${ }^{2}$ Id. at 442 .

3 See José E. Alvarez, The Relativity Apocalypse Is Nigh, 114 AJIL Unbound 77 (2020).

${ }^{4}$ Weil, supra note 1 , at $418-19$.

(C) John Tasioulas 2020. This is an Open Access article, distributed under the terms of the Creative Commons Attribution licence (http://creativecommons.org/licenses/by/4.0/), which permits unrestricted re-use, distribution, and reproduction in any medium, provided the original work is properly cited. 
coexistence and cooperation, whether it should aim even higher in its goals, and how any additional goals are to be integrated with the first two. One important question that Weil sets for us is the extent to which the pursuit through international law of laudable goals, especially those associated with human rights, can be legitimate and effective. Ingrid Wuerth, in an excellent recent article, has argued that the uncritical pursuit of an ambitious human rights agenda has distorted international law in ways damaging to its capacity to serve the foundational goals of international peace and security. ${ }^{5}$ This is precisely the kind of ongoing, deep-level engagement with the themes in Weil's great article that we need.

But there is a second reason for taking Weil seriously today. Although relative normativity is now well-established as a matter of practice, this is not always properly acknowledged at the level of international lawyers' reflective self-understanding. Indeed, Weil already observed the tendency for relativist substance to be concealed by traditional, PVA-style pronouncements: "behind the mask of classicism. . . there has been a change of substance." The "mask of classicism" phenomenon is not simply a matter of the inherently troubling cognitive dissonance arising from the discrepancy between self-understanding and practice. If this phenomenon exists, as I believe it does, failure to address it enhances the likelihood that relative normativity will be damaging in some of the ways Weil feared. This is because the relativist trend can be safeguarded against the dangers that Weil foreshadowed only if international lawyers candidly acknowledge their departure from the PVA and are equipped with a principled basis for their relativist doctrinal innovations.

As an illustration of the "mask of classicism" problem, consider Weil's critique of relativist tendencies in relation to customary international law. One strand of his criticism focuses on the way in which custom, under the relativist dispensation, is all too readily adduced without significant support in state practice, but rather on the basis of an emergent "consensus" among states, with the ensuing rule being made opposable against all states, even those that were not part of the consensus or that even persistently objected to it during its formation. ${ }^{7}$ Key to this process is a value judgment that justifies asserting the existence of such a rule despite the absence of strong supporting state practice or individual consent, a judgment that contravenes the demands of positivism and neutrality. The lamentable effects of this relativist account, according to Weil, include indeterminacy as to which customary norms exist and a failure to respect the radical ideological pluralism of the international legal order. This is a rich set of criticisms, against which I have elsewhere sought to defend the relativist approach to customary international law. ${ }^{8}$

Let me set against Weil's pessimism an analysis of a very different tenor. In reply to those, such as Weil and others, who claim that customary international law faces a legitimacy crisis, this analysis offers the following upbeat assessment:

Such a bleak outlook, we would argue, does not correspond to reality: in fact, customary international law has probably never been in better shape. Not only is it not in crisis in this (ever-)changing world in which it has to operate, but its role in the international legal system continues to be fundamental. Furthermore, recognition of its significance and confidence in its operation are evident in the recent work of the International Law Commission on the topic "Identification of customary international law." While academic disputes surrounding the nature and function of custom may indeed endure, in practice some

\footnotetext{
${ }^{5}$ Ingrid Wuerth, International Law in the Post-Human Rights Era, 96 Tex. L. Rev. 279 (2017).

${ }^{6}$ Weil, supra note 1 , at 438.

${ }^{7}$ Id. at $437-38$.

${ }^{8}$ See the Nicaragua case, which I have defended in these terms in John Tasioulas, In Defence of Relative Normativity: Communitarian Values and the Nicaragua Case, 16 Oxford J. Legal STUd. 85 (1996).
} 
long-standing questions have by now been settled, and others do not prevent custom from continuing to play an important role as positive international law in force. ${ }^{?}$

The coauthor of these words is the British international lawyer, Sir Michael Wood, who is the International Law Commission's (ILC's) Special Rapporteur on the topic of “Identification of Customary International Law." But, on reflection, it is hard to avoid the conclusion that this passage skates too lightly over deep concerns that Weil, and others, have articulated about customary international law.

Let me try to make good on this claim by taking the ILC's conclusions and commentaries, which strongly endorse the traditional "two element" view of custom, as an illustration of the "mask of classicism" problem. ${ }^{10}$ As we have seen, Weil strenuously defended the "two element" view, which demands both state practice and opinio juris for the formation of customary international law, against relativist tendencies that systematically discounted the importance of the practice element. This stress on state practice is fully in line with Weil's positivist and voluntarist strictures: state practice is something that can be discerned without making a value judgment, and states actually conforming with a putative rule (rather than merely verbally expressing their acceptance of it) may reasonably be taken to be manifesting a distinctively robust commitment to it. Now, the ILC Draft Conclusions officially endorses the two element view in its Conclusion 2: "To determine the existence and content of a rule of customary international law, it is necessary to ascertain whether there is a general practice that is accepted as law (opinio juris)." 11 Moreover, it dismisses the idea, accepted by opponents and defenders of relative normativity alike, that the two element view is not strictly adhered to in contemporary international law. ${ }^{12}$ But this invocation of a traditionalist view of custom as a matter of settled doctrine has all the hallmarks of a "mask of classicism" that conceals relativist realities. This emerges in at least three ways.

First, insisting on both state practice and opinio juris as necessary to the existence of custom means little if the distinction between these two elements is systematically blurred, with the result that what counts as evidence of state practice significantly overlaps with what counts as evidence of opinio juris. As I argued in an earlier piece, there was a serious problem of "double-counting" of this sort in the Special Rapporteur's Second Report. ${ }^{13}$ In the final version of the conclusions, the Special Rapporteur goes a little way towards addressing this problem by revising the specification of the respective kinds of evidence of state practice and opinio juris so as to mitigate the impression of massive overlap. ${ }^{14}$ But this seems a largely cosmetic measure. We are still left with the question of whether the kind of evidence that grounds a customary norm, on this revised view, could be substantially_or almost exclusively—

\footnotetext{
${ }^{9}$ Omri Sender \& Michael Wood, Custom's Bright Future: The Continuing Importance of Customary International Law, in CusTOM's FutURE: International Law in a Changing World 360, 360-61 (Curtis A. Bradley ed., 2016).

${ }^{10}$ Int'l Law Comm'n, Draft Conclusions on Identification of Customary International Law, with Commentaries, UN Doc. A/73/10 (2018) [hereinafter Draft Conclusions].

11 Id. at 119.

12 Id. at 126 .

13 See Draft Conclusions 7(2) at 21 on evidence of state practice and Draft Conclusion 11(2) at 67 on opinio juris in Michael Wood (Special Rapporteur, Int'l Law Comm'n), Second Report on Identification of Customary International Law, UN Doc. A/CN.4/672 (2014). For my previous discussion of this “double-counting," see John Tasioulas, Customary International Law: A Moral Judgment-Based Account, 2015 ASIL PROC. 328, 331.

${ }^{14}$ Forms of state practice are taken to "include diplomatic acts and correspondence; conduct in connection with resolutions adopted by an international organization or at an intergovernmental conference; conduct in connection with treaties; executive conduct, including operational conduct "on the ground"; legislative and administrative acts; and decisions of national courts" (Conclusion 6(2)). Forms of opinio juris are taken to include "public statements made on behalf of States; official publications; government legal opinions; diplomatic correspondence; decisions of national courts; treaty provisions; and conduct in connection with resolutions adopted by an international organization or at an intergovernmental conference" (Conclusion 10(2)).
} 
that which (also) goes towards proving opinio juris. Such a possibility seems to be countenanced in the ILC's commentary on Conclusion 2:

$[T]$ he paragraph does not exclude that the same material may be used to ascertain practice and acceptance as law (opinio juris). A decision by a national court, for example, could be relevant practice as well as indicate that its outcome is required under customary international law. Similarly, an official report issued by a State may serve as practice (or contain information as to that State's practice) as well as attest to the legal views underlying it. The important point remains, however, that the material must be examined as part of two distinct inquiries, to ascertain practice and to ascertain acceptance as law. ${ }^{15}$

But this concluding "important point" risks being robbed of practical force if it is largely, or even entirely, the same evidence that is appealed to in both of the inquiries, since no principled criterion for the supposed distinction between the two inquiries has been elaborated. An analysis that heeded the importance of the distinction between the two elements would, I believe, have taken greater pains to emphasize that state practice consists in state activity in line with the putative norm, whether this be its primary or secondary (e.g., responses to perceived violations, etc.) normative significance. Yet just such an interpretation is dismissed by the commentary accompanying the ILC's conclusions: " $[\mathrm{t}$ is now generally accepted that verbal conduct (whether written or oral) may also count as practice; indeed, practice may at times consist entirely of verbal acts, for example, diplomatic protests." 16 However, if practice can consist entirely of verbal acts, which presumably also count as opinio juris, it is mystifying why such great store is placed on the two element view by the ILC Report.

A second way in which the ILC Report dons a mask of classicism is by unjustifiably assuming that key official pronouncements regarding the formation of customary international law, which have a classicist tenor, are generally adhered to in practice. The obvious problem here is that if the official pronouncement is a mask that disguises reality, then taking it at face value is itself a form of masking in turn. Instructive here is the Report's engagement with the Nicaragua case, ${ }^{17}$ a judgment in which many commentators have discerned the operation of a strong relativist account of custom, one that heavily prioritizes opinio juris and allows significant inconsistent state practice to be traded off against such consensus on the basis of a sliding scale that is sensitive to the moral attractiveness of the norm in question. ${ }^{18}$ How does the Report square the Nicaragua judgment with its own repeated insistence that the state practice grounding a putative customary norm must be "virtually uniform"? 19 First, it simply denies that the ICJ's judgment countenances any kind of sliding scale approach to the relationship between opinio juris and state practice. ${ }^{20}$ But this denial is not defended by reference to the actual reasoning process followed by the Court in Nicaragua (which may in fact receive illicit support from the Report's adoption of a significantly overlapping interpretation of the two elements). Second, it appeals to a tactic deployed in the Nicaragua judgment itself, whereby purportedly inconsistent state practice can be discounted if it is accompanied by an opinio juris to the effect that it is consistent with existing law. ${ }^{21}$ But there is a real question here whether the use of opinio juris to negate apparently contrary state practice really preserves a robust version of the two element view rather than, fundamentally, exemplifying the consensus-driven account of custom that triggered Weil's alarm.

${ }^{15}$ Draft Conclusions, supra note 10, at 129.

${ }^{16}$ Id. at 133 .

${ }^{17}$ Military and Paramilitary Activities in and Against Nicaragua (Nicar. v. U.S.), Merits, 1986 ICJ ReP. 14 (June 27).

${ }^{18}$ Frederic L. Kirgis, Custom on a Sliding Scale, 81 AJIL 146 (1987); Tasioulas, supra note 8.

19 A requirement stressed by the Draft Conclusions, supra note 10, echoing the North Sea Continental Shelf Cases, id. at 136, and the Nicaragua case itself, $\underline{i d}$. at 137.

${ }^{20}$ Id. at 126.

${ }^{21} \mathrm{Id}$. at $137-38$. 
Perhaps this all misses the more significant way in which the ILC Report pays tribute to the PVA, which is its strong insistence, in Conclusion 15, that the formation of customary international law is subject to the "persistent objector" rule. ${ }^{22}$ And it is the unequivocal endorsement of this rule, it might be thought, that is the true litmus test of fidelity to a view of custom in line with the PVA, addressing as it does Weil's main concern about customary international law illegitimately "slithering" to a general rule opposable to all states irrespective of their will. ${ }^{23}$ There is of course a grain of truth in this response, but no more than a grain. As Weil's analysis recognizes, the class of peremptory norms of jus cogens are paradigmatically thought to be opposable against all states irrespective of their volition. Indeed, on one analysis, jus cogens norms are standardly norms of customary international law that are distinguished from the rest of their class by the combined possession of three features: (a) universality (they bind all states); (b) peremptoriness (they bind irrespective of individual state consent), and (c) non-derogability (non-compliance cannot be justified, except perhaps insofar as this is permitted by another norm that also has jus cogens status). ${ }^{24}$ But the ILC's Draft Conclusions simply bracket the whole issue of jus cogens norms, concluding that it is "without prejudice to any question concerning peremptory norms of general international law (jus cogens)." 25 Therefore, we do not have an answer to the question whether jus cogens norms are typically customary international norms or, instead, as Antonio Cassese has suggested, ${ }^{26}$ they form a sui generis source of law grounded in international consensus and exempt from the need for a basis in state practice. More importantly, there is no engagement with the question whether jus cogens norms are subject to the persistent objector rule. For all the ILC tells us, there may be a large and demanding set of peremptory norms of jus cogens to which states are subject even if they have persistently objected to them during the process of their formation. ${ }^{27}$ The invocation of the persistent objector rule is potentially a classicist mask that conceals a starkly different reality.

Like the Roman emperor Augustus, who established a monarchy behind the façade of restoring republican institutions, many international lawyers, whether knowingly or not, deploy a "mask of classicism" that disguises relativist realities. The great merit of Prosper Weil's famous article is to alert us to those realities and the risks they pose in the eyes of anyone committed to the classic PVA framework of international law. My own view is that the PVA framework invoked by Weil is itself flawed, and that many of the relativist developments that he condemns can be given an alternative theoretical basis. But little progress can be made in this endeavor if we are lulled into denying or downplaying their very existence. Moreover, the need to provide such a principled grounding is especially urgent at a time when there is reason to fear that an unacknowledged and unprincipled commitment to relative normativity might be hijacked by authoritarian tendencies that are increasingly manifesting themselves in international law. ${ }^{28}$

22 Id. at 152.

${ }^{23}$ Weil, supra note 1 , at 437.

${ }^{24}$ John Tasioulas, Custom, Jus Cogens, and Human Rights, in Custom's Future, supra note 9, at 95, 107.

${ }^{25}$ Id. at 154.

${ }^{26}$ Antonio Cassese, A Plea for a Global Community Grounded in a Core of Human Rights, in ReAlizing Utopia: The Future of INTERNATIONAL Law (Antonio Cassese ed., 2012).

${ }^{27}$ Dire Tladi, the ILC's Special Rapporteur on Peremptory Norms of General International Law (jus cogens), has written that the extension of the persistent objector rule to jus cogens norms "would go against the very notion of universal applicability of jus cogens." Int'l Law Comm'n, Third Report on Peremptory Norms of General International Law (jus cogens), UN Doc. A/CN.4/714, at 58, para. 143 (2018).

28 Tom Ginsburg, Authoritarian International Law, 114 AJIL (forthcoming 2020). 